\title{
IMPLEMENTASI MEDIA AUDIO VISUAL DALAM PEMBELAJARAN IPA BIOLOGI MATERI VIRUS PADA SISWA KELAS XA DI MA QUR'ANIYAH BATU KUTA NARMADA DALAM MENINGKATKAN AKTIVITAS BELAJAR TAHUN PELAJARAN 2015/2016
}

\author{
Fendi Hidayat ${ }^{1}$, Suhirman ${ }^{2}$, dan Adi Fadli ${ }^{3}$ \\ ${ }^{1}$ Mahasiswa Jurusan Tadris IPA Biologi FITK IAIN Mataram \\ ${ }^{2}$ Dosen FITK IAIN Mataram
}

\begin{abstract}
Abstrak
Terkait dengan rumusan masalah yang diangkat, maka tujuan yang ingin dicapai dalam penelitian ini adalah untuk mengetahui apakah ada peningkatan aktivitas belajar siswa Kelas X A dengan mengimplementasikan media audio visual dalam pembelajaran IPA biologi materi virus di MA Qur"aniyah Batu Kuta Naramada Tahun Pelajaran2015/2016.Penelitian ini mengunakan penelitian tindakan kelas (PTK).Subjek penelitian ini adalah siswa kelas X MA Qur"aniyah Batu Kuta Narmada Tahun Pelajaran 2015/2016 yang bejumlah 31 yang dijadika Subjek penelitian.Teknik pengumpulan data meng-gunakan Observasi, Dokumentasi. Dari analisi observasi siklus I mendapatkan hasil $60 \%$ dengan criteria siswa yaitu cukup Aktif di dalam proses pembelajaran, sedangkan pada siklus II menda-patkan hasil 86\%. Dari hasil siklus I dengan siklus II, maka peneliti dapat mengemukakan terdapat peningkatan aktivitas belajar dengan implementasikan Media Audio Visual Pada siswa Kelas X MA Qur"aniyah Batu Kuta Narmada m Tahun Pelajaran 2015/2016. Dengan demikian Implementasi Media Audio Visual dapat meningkatkan aktivitas belajar siswa.
\end{abstract}

Kata kunci : Bakteri Pendegradasi Protein dan Limbah Tahu. 


\section{PENDAHULUAN}

Perkembangan ilmu pengetahuan dan teknologi membawa perubahan dihampiri semua aspek kehidupan manusia, termasuk dalam pendidikan formal. Pendidikan merupakan suatu yang penting dalam kehidupan manusia. Pendidikan adalah usaha sadar dan terencana untuk mewujudkan suasana belajar dan proses pembelajaran agar peserta didik secara aktif mengembangkan potensi dirinya untuk memiliki kekuatan spritual keagamaan, pengendalian diri, keperibadian, kecerdasan, akhlak mulia, serta keterampilan yang diperlukan dirinya dan masyarakat. Masyhuri di dalam bukunya meragumentasi tentang ilmu pengetahuan dan mengatakan bahwa ilmu pengetahuanadalah seluruh informasi yang mengandung pengetahuan tentang sesuatu kejadian yang terjadi di alam empirik atau alam yang dapat ditangkap oleh panca indra kita.

Keberhasilan penerapan kompetensi suatu mata pelajaran bergantung kepada beberapa aspek antara lain ialah siswa, guru, mata pelajaran, kurikulum, metode pengajaran, sarana dan prasarana. Salah sau aspek yang paling mempengaruhi keberhasilan pencapaian kompetensi yaitu guru, sebab gurulah yang terlibat langsung dalam upaya mempengaruhi, membina, dan mengembangkan kemampuan peserta didiknya supaya menjadi cerdas, terampil, dan bemoral tinggi serta berjiwa sosial sehngga siswa mampu mandiri sebagai makhuk individu maupun sosial. Selain guru, aspek yang paling mempengaruhi keberhasilan pencapaian kompetensi yaitu cara atau metode guru dalam menyampaikan materi pembelajaran. Kecenderungan yang terjadi pada proses pembelajaran di indonesia adalah kgiatan belajar masih berpusat pada guru. Guru lebih banyak bercerita dan mencatat, siswa pun banyak yang tidak aktif terlibat dalam akifitas belajar mengajar, selain itu guru kurang atau jarang menggunakan media pembelajaran sehingga proses pembelajaran menjadi pasif dan kurang bermanfaat.

Dalam pembelajaran IPA Biologi, kualitas pembelajaran tampak masih menjadi sorotan dalam dunia pendidikan di tanah air. Siswa masih menganggap bahwa materi pembelajaranIPA Biologi merupakan materi yang membosankan dan banyak 
teorinya, selain itu banyak diantara siswa menganggap pelajaran IPA Biologi adalah suatu yang memusingkan. Adanya anggapan tersebut menjadikan proses belajar tidak menarik sehingga menggangu aktivitas belajar mengajar dan hasil belajar siswa pun rendah. Hal ini dirasakan oleh siswa MA Qur"aniyah Batu Kuta Narmada, dan berdasarkan hasil observasi awal pada hari jumat 23 oktober 2015 dengan guru mata pelajaran IPA Biologi yaitu Amrul Jihadi, S.P., menyatakan bahwa rendahnya hasil belajar siswa dalam mata pelajaran Biologi dipengaruhi oleh rendahnya sarana prasarana seperti media yang digunakan oleh guru sehingga aktivitas belajar siswapun tentunya mengalami penurunan. Haltersebut terlihat dari hasil nilai yang diperoleh siswa mencapai rata-rata 50 dengan kata lain belum mendekati ketuntasan minimal yang telah ditentukan yaitu 65.

Keadaan tersebut perlu diperhatikan oleh seorang pendidik khususnya guru mata pelajaran IPA Biologi agar selalu berusaha untuk menciptakan inovasi dalam pembelajaran sebagai solusi untuk meningkatkan daya tarik siswa dalam pembelajaran IPA sehingga aktivitas belajar siswa menjadi menarik dan prestasi siswa pun mengalami peninggakatan. Diantara inovasi tersebut yaitu dengan mengembangkan metode dan media pembelajaran yang sesuai.

Dengan memperhatikan berbagai kegunaan media dan macam-macam media serta dengan memperhatikan modalitas yang dimiliki siswa yang telah dipaparkan di atas, maka peneliti akan mencoba menggunkan media audio visual. Media audio visual yaitu media pandang-dengar. Media audio visual akan menjadikan penyajian bahan ajar kepada siswa semakin lengkap dan optimal sesusai dengan modalitas belajar siswa sehingga diharapkan siswa akan lebih paham akan materi pembelajaran yang dipelajari dan meningkatkan aktivitas serta prestasi belajar siswa. Selain itu media audio visual ini juga tidak hanya digolongkan sebagai pengalaman belajar yang diperoleh dan penginderaan, tetapi sebagai alat teknologis yang bisa memperkaya serta memberikan pengalaman yang bersifat kongkrit kepada siswa. 


\section{METODE PENELITIAN}

\section{Desain Penelitian}

Penelitian ini adalah penelitian tindakan kelas (classroom Action Reseach). Penelitian tindakan kelas adalah penelitian yang dilakukan oleh guru di kelasnya sendiri dengan melalui reflek diri dengan tujuan yang memperbaiki kinerjanya sehingga hasil belajar siswa meningkat. Penelitian tindakan kelas, sangat terkait dengan judul yang peneliti angkat karena mengacu kepada permasalahan yang ada di lapangan. Penelitian ini di lakukan di MA Qur'aniyah Batu Kuta Narmada.

\section{Prosedur Penelitian}

Prosedur penelitian ini dilaksanakan dalam 2 (dua) siklus. Setiap siklus terdiri dari empat tahap: perencanaan, pelaksanaan tindakan, monitoring observasi tindakan, dan refeleksi hasil monitoring. Pada tahap perencanaan kegiatan yang dilakukan adalah, membuat rencana pembelajaran, membuat sekenario pembelajaran, membuat lembar observasi untuk mengetahui aktivitas belajar siswa. Pada tahap pelaksanakan tindakan kegiatan yang dilakukan adalah melaksanakan pembelajaran yang telah direncanakan dalam sekenario pembelajaran. Pada tahap observasi, aktivitas belajar siswa dan hal-hal yang terkait dengan pembelajaran dilakukan dengan pengamatan langsung di dalam kelas. Observasi dilakukan oleh peneliti dan guru bidang studi biologi selaku observer yang bertujuan untuk mengetahui apakah pembelajaran sudah sesuai dengan skenario yang telah dibuat.

\section{Teknik Pengumpulan Data}

Teknik pengumpulan data adalah cara yang dilakukan untuk memperoleh data atau informasi. Dalam penelitian ini diambil 3 cara, yaitu:

\section{Observasi}

Observasi diartikan sebagai pengamatan dan pencatatansecara sistematik terhadap gejala yang tampak pada objek penelitianpengamatan dan pencatatan ini 
dilakukan terhadap objek di tempat berlangsungnya peristiwa.Dalam penelitian ini, observasi digunakan untuk memperoleh data aktivitas siswa pada saat proses belajar berlangsung.

2. Wawancara

Wawancar digunakan untuk melengkapi hasil pene-litiandi luar kelas untuk mendapatkan data yang falid.

3. Dokumentasi

Dokumentasi digunakan untuk membuktikan bagai-mana proses penelitian di lapangan berlangsung baik itu berupa foto atau vidio.

\section{Analisi Data}

Data hasil observasi aktivitas siswa selama proses pembelajaran berlangsung dianalisis dengan menggunakan rumus berikut:

$$
N=\frac{\text { Jumlahh } \text { skor yang diperoleh h siswa }}{\text { Jumlah hindikator }} 100 \%
$$

\section{HASIL PENELITIAN DAN PEMBAHASAN}

Dari hasil pelaksanaan tindakan dalam implementasi media audio visual dalam pembelajaran IPA Biologi dalam meningkatkan aktivitas belajar, pada siklus I dan siklus II menunjukkan adanya peningkatan aktivitas belajar siswa. Hal ini terbukti dengan semakin meningkatnya perolehan persentase tiap siklusnya, walaupun dalam siklus I belum mencapai aktivitas belajar yang aktif, akan tetapi dari hasil siklus I sampai siklus II terjadi peningkatan aktivitas belajar yang dibuktikan oleh hasil analisis aktivitas belajar siswa. Hal ini terbukti dengan semakin meningkatnya perolehan persentse tiap siklusnya, walaupun 
dalam siklus I belum mencapai ketuntasan belajar, akan tetapi dari hasil siklus I sampai siklus II terjadi.

Pada siklus I diperoleh nilai skor 60\% yang terkategori cukup aktif aktivitas belajar siswa kelas XA MA Qur"aniyah Batu Kuta Narmada. Dengan belum tercapainya ketuntasan klasikal pada siklus I di sebabkan karena beberapa faktor yaitu faktor yang berasal dari guru dan faktor yang berawal dari siswa. Faktorfaktor tersebut berkaitan langsung dengan implementasi media audio visual yang belum berjalan secara maksimal. Salah satu yang menjadi kekurangan guru pada siklus I ini, kurangnya bimbingan dan pengarahan yang di berikan pada saat proses belajar mengajar.

Faktor yang berasal dari siswa, adanya salah satu dampak dari adanya siswa yang tidak serius dan masih main-main. Kekurangan yang muncul dari faktor siswa juga pada akhir pelajaran (penutup), siswa masih takut dan ragu dalam menyimpulkan materi, sehingga menyebabkan guru harus menyimpulkan sendiri.

Pada siklus II berdasarkan hasil observasi, siswa memperoleh skor $86 \%$ dan di kategorikan aktif. Jadi dalam siklus II ini terdapat peningkatan aktivitas belajar siswa dari siklus I sampe siklus II, Ketercapaian peningkatan aktivitas belajar siswa pada siklus II menunjukkan bahwa implementasi media audio visual dalam pembelajaran IPA biologi materi virus pada siswa kelas XA MA Qur"aniyah Batu Kuta Narmada dapat meningkatkan aktivitas belajar.

Dengan implementasi media audio visual pada mata IPA biologi menjadi lebih menarik dan mudah dipelajari karena siswa dilatih menggunakan kedua indranya yaitu indra pendengaran dan pengelihatan sehingga dapat mengingat pembelajaran yang telah didapatinya dengan jangka panjang. 


\section{PENUTUP}

\section{Kesimpulan}

Dari hasil pelaksanaan tindakan dalam implementasi media audio visual dalam pembelajaran IPA biologi materi virus pada siswa kelas XA MA Qur"aniyah Batu Kuta Narmada dalam meningkatkan aktivitas belajar. Pada siklus I dan siklus II menunjukkan adanya peningkatan aktivitas belajar siswa. Hal ini terbukti dengan semakin meningkatnya perolehan persentase tiap siklusnya, walaupun dalam siklus I belum mencapai kategori aktif, akan tetapi dari hasil siklus I sampai siklus II terjadi peningkatan aktivitas belajar siswa yang dibuktikan oleh hasil analisis aktivitas belajar siswa kelas XA MA Qur"aniyah Batu Kuta Narmada.

Implementsi media audio visual dalam pembelajaran IPA biologi di Madrasah Aliyah Qur"aniyah Batu Kuta Narmada. Meskipun telah memenuhi beberapa kriteria yang dituntut dalam pelaksanaan pembelajaran IPA biologi, namun efektivitas pembelajaran IPA Biologi belum efektif. Mengingat beberapa indikator yang menunjukkan efektifitasnya pembelajaran tersebut belum memadai, karena masih kurangnya sarana dan prasarana seperti: tidak ada laboratorium IPA dan karena faktor lingkungan dimana tidak diterapkannya media audio visual disetiap pembelajaran IPA biologi sehari-harinya.

\section{Saran}

Melalui tulisan penelitianini penulis menyampaikan beberapa saran yang kiranya dapat digunakan dalam meningkatkan aktivitas belajar siswa dalam pembelajaran IPA Biologi di Madrasah Aliyah Qur"aniyah Batu Kuta Narmada. Saran-saran yang dimaksud akan penulis tujukan kepada:

1. Kepala sekolah, guru-guru (tenaga pengajar di madrasah aliyah qur"aniyah) batu kuta narmada.

a. Untuk lebih efektifnya pembelajaran di Madrasah Aliyah Qur"aniyah peran kepala sekolah adalah hendaknya memberikan bantuan kepada para guru dalam rangka melengkapi alat-alat pembelajaran seperti buku- buku, 
pengadaan alat bantu belajar, pengadaan perpustakaan, dan media pembelajaran. Sebab bagaimanapun semua fasilitas sangat berpengaruh terhadap kegiatan penbelajaran.

b. Usaha-usaha untuk menggunakan system pengajaran harus dilakukan terus terutama mengenai media pembelajaran agar pembelajaran lebih bervariasi dan menarik.

c. Bagi setiap guru dalam melaksanakan tugas mulianya diharapkan akan senantiasa terus menerus memotivasi para siswanya dan sekereatif mungkin mengadakan mediamedia yang efektif dan efesien, mengingat fasilitas yang ada masih sangatlah minim.

2. Para siswa

a. Para siswa hendaknya mentaati peraturan sekolah tempat saudara belajar.

b. Para siswa hendaknya selalu aktif dalam mengikuti semua kegiatan- kegiatan yang mengantarkan saudara ke arah kesuksesan demi masa depan saudara.

\section{DAFTAR PUSTAKA}

Iskandar, Metodologi Penelitian Pendidikan, (Jakarta: Gaung Persada Press,2011)

Joko sucipto, Evaluasi dan Remediasi Belajar, (Jakarta: CV Trans Info Media, 2009)

Lexy J. Moleong, Metode Penelitian Kualitatif, (Bandung: Rosda Karya, 2005) Mashury. metodologi penelitian pendekatan praktis dan aplikatif.(PT: PetikaAditama.2008),

Nana Syaodih Sukmadinata, Metode Penelitian Pendidikan, (Bandung: Remaja Rosdakarya, 2010)

Oemar Hamalik. Kurikulum dan Pembelajaran. (jakarta: Bumi Aksara,2008)

Rudihartono, ragam model mengajaryangmudah diterimamurid, 
Implementasi Media Audio Visual...

(Jogjakarta: DIVApress)

Sugiono, Metodologi Penelitian Kuantitatif, Kualitatif dan $R$ dan D, (Bandung: Alfabeta, 2011)

Subandi.Mikrobiologi Perkembangan, Kajian, dan Pengamatan dalam Persefektif Islam. (Bandung: PT Remaja Rosdakarya. 2010)

SuharsimiArikunto, Dasar-Dasar Evaluasi Pendidikan, (Jakarta: PT Bumi Griya, 2009) 